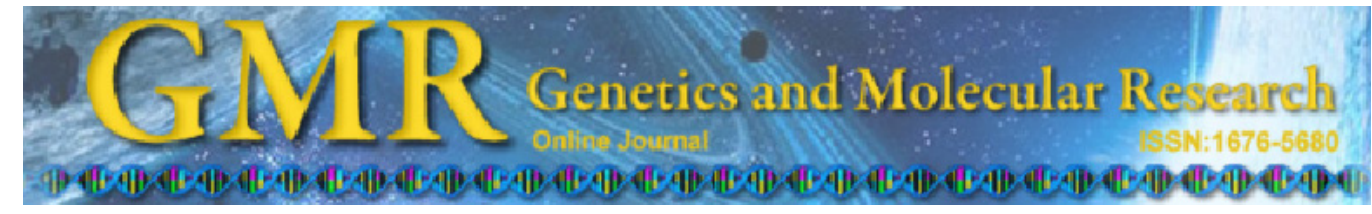

Methodology

\title{
An improved protocol and a new grinding device for extraction of genomic DNA from microorganisms by a two-step extraction procedure
}

\author{
S.S. Zhang, D. Chen and Q. Lu \\ State Key Laboratory of Non-Food Biomass Enzyme Technology, \\ National Engineering Research Center for Non-Food Biorefinery, \\ Guangxi Key Laboratory of Biorefinery, Guangxi Academy of Sciences, \\ Nanning, Guangxi Province, China \\ Corresponding author: D. Chen \\ E-mail: chendongqiushui@163.com
}

Genet. Mol. Res. 11 (2): 1532-1543 (2012)

Received January 9, 2012

Accepted February 25, 2012

Published May 21, 2012

DOI http://dx.doi.org/10.4238/2012.May.21.10

\begin{abstract}
Current protocols to extract genomic DNA from microorganisms are still laborious, tedious and costly, especially for the species with thick cell walls. In order to improve the effectiveness of extracting DNA from microbial samples, a novel protocol, defined as two-step extraction method, along with an improved tissue-grinding device, was developed. The protocol included two steps, disruption of microbial cells or spores by grinding the sample together with silica sand in a new device and extraction of DNA with an effective buffer containing cell lysis chemicals. The device was prepared by using a commercial electric mini-grinder, adapted with a grinding stone, and a sample cup processed by lathing from a polytetrafluoroethylene rod. We tested the method with vegetative cells of four microbial species and two microbial spores that have thick cell walls and are therefore hard to process; these included Escherichia coli JM109, Bacillus subtilis WB600, Sacchromyces cerevisiae INVSc1, Trichoderma viride AS3.3711, and the spores of S. cere-
\end{abstract}


visiae and T. viride, respectively, representing Gram-positive bacteria, Gram-negative bacteria, yeast, filamentous fungi. We found that this new method and device extracted usable quantities of genomic DNA from the samples. The DNA fragments that were extracted exceeded $23 \mathrm{~kb}$. The target sequences up to about $5 \mathrm{~kb}$ were successfully and exclusively amplified by PCR using extracted DNA as the template. In addition, the DNA extraction was finalized within $1.5 \mathrm{~h}$. Thus, we conclude that this two-step extraction method is an effective and improved protocol for extraction of genomic DNA from microbial samples.

Key words: DNA extraction; Electric mini-grinder; Silica sand

\section{INTRODUCTION}

Preparation of DNA is an essential step for nearly all studies related to molecular biology. Currently, the preparation of genomic DNA from microorganisms generally involves three major steps: cell disruption, DNA extraction and purification. The genomic DNA is usually extracted with an extraction buffer, and then purified by phenol/chloroform extraction followed by isopropanol or ethanol precipitation (Fredricks and Relman, 1998). The results of DNA preparation (yield, purity, fragment length, etc.) to a great extent depend on the cell disruption and extraction buffer. A variety of methods to break down the microbial cell wall have been reported. The most common method is by grinding the microbial cells or mycelia together with silica sand or glass bead in liquid nitrogen (Karakousis et al., 2006) or in dry ice (Clark-Curtiss et al., 1985). In addition, many alternative methods, including the glass or magnetic bead method (Melo et al., 2006), enzyme digestion (Griffiths et al., 2006), benzyl chloride method (Yamamoto et al., 1995), microwave exposure method (Tendulkar et al., 2003), heating method (Zhang et al., 2010), freezing method (Harju et al., 2004), and combinations of different methods (Liu et al., 2011), etc., have also been reported for disruption of microbial cells. Although these techniques generally provide DNA with satisfactory quantity and quality, most of them are still laborious, tedious and time-consuming, and apparently cannot meet the requirements for the preparation of genomic DNA from a large number of microbial samples. In order to reduce the amount of labor and to speed up the preparation of DNA, the commercial grinding apparatus for cell disruption and a variety of DNA isolation kits are already available on the international market, but the high price of the commercial grinding apparatus and the elevated cost for extraction of large amounts of DNA are not easily accepted by most laboratories, especially by those in developing countries with limited financial support. Chi et al. (2009) have reported a QS (quick and safe) method for extraction of genomic DNA from fungi by using a simple device. In this investigation, we propose a more effective method for extraction of genomic DNA from various microbial samples by using a two-step extraction procedure and a simple self-design device.

\section{MATERIAL AND METHODS}

\section{Device}

The device used for experiments is shown in Figure 1. A is a commercial electric 
mini-grinder ( $100 \mathrm{~W}, 220 \mathrm{~V})$, with a continued adjustable rotation speed of 8000 23,000 rpm, produced by Wanneng Electrical Tools Company Ltd., China. B is the adaptor of the grinder. $\mathrm{C}$ is a commercial grind stone, cylinder shape, with $10 \mathrm{~mm}$ in diameter and $8 \mathrm{~mm}$ high. $\mathrm{D}$ is a sample cup, with an inner dimension of $11 \mathrm{~mm}$ in diameter, $33 \mathrm{~mm}$ depth and outside dimension of $21 \mathrm{~mm}$ in diameter, $43 \mathrm{~mm}$ high, prepared by lathing from a polytetrafluoroethylene rod. When processing the sample cup, the inner diameter of the cup was required to be $1.0 \sim 1.5$ $\mathrm{mm}$ larger than the diameter of grind stone, and the depth of cup was required to be 20 25 mm longer than the height of the grind stone. A larger grind stone and a matched sample cup could be used for single extraction of more DNA. To perform the experiment, the grind stone was clamped onto the grinder by tightening the adaptor's screw with the spanner. The grinder and sample cup was easily held by hand during grinding of the sample. One device can be used for extraction of DNA from various microbial samples by changing the sample cup and the grind stone is ready. The grind stone can be easily changed from the grinder within $1 \mathrm{~min}$. However, for comparison of results, only one set of sample cup and grind stone was used for our experiments, and to avoid cross-contamination, the sample cup and grind stone were washed clean and decontaminated completely after one extraction was completed.

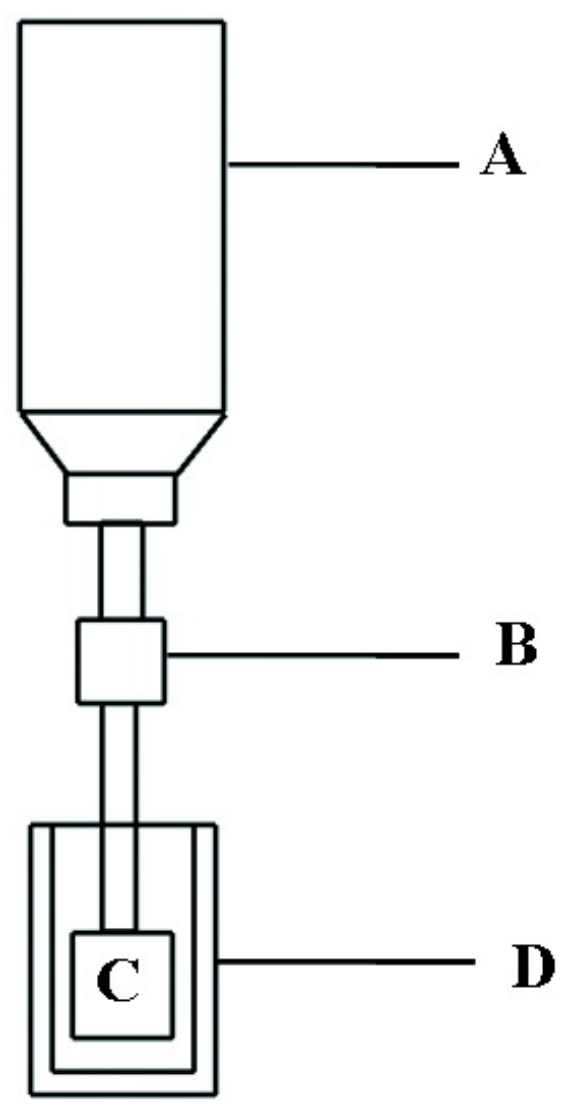

Figure 1. Device used in this study. $A=$ Commercial electric mini-grinder; $B=$ adaptor of grinder; $C=$ commercial grind stone; $\mathrm{D}$ = sample cup prepared by lathing from polytetrafluoroethylene rod. 


\section{Strains}

For investigating the feasibility of method for preparation of genomic DNA from various microorganism samples, the vegetative cell of four microbial strains, Escherichia coli JM109, Sacchromyces cerevisiae INVSc1, Trichoderma viride AS3.3711 and Bacillus subtilis WB600, and the spores of $S$. cerevisiae MF1005 and T. viride AS3.3711 were used for the studies. The first three strains were purchased from Promega, Invitrogen and Agricultural Culture Collection of China, respectively. B. subtilis WB600 was obtained from Jiangnan University, Wushi, Jiangsu, China. S. cerevisiae MF1005 was screened by our laboratory from the waste of a sugar mill in Guangxi Province, southern China. The spore was obtained from cultivation.

\section{Media and culture conditions}

E. coli and B. subtilis were cultivated, respectively, in LB medium (containing $1 \%$ peptone, $0.5 \%$ yeast extract, $1 \% \mathrm{NaCl}$ ) (Sambrook and Russell, 2001) and nutrient medium (containing 3\% peptone, $1.5 \%$ beef extract, $1.5 \%$ yeast extract and $2.5 \% \mathrm{NaCl}$ ) (Rajagopalan and Krishnan, 2008) overnight at $37^{\circ} \mathrm{C}$, shaken at $200 \mathrm{rpm}$. S. cerevisiae and T. viride were cultured, respectively, in YPD medium (1\% yeast extract, $2 \%$ peptone and $2 \%$ glucose ) (Sambrook and Russell, 2001) overnight and in YPDM medium (containing 1\% yeast extract, $2 \%$ peptone, $2 \%$ glucose and $1 \%$ malt extract) (Okada et al., 1998) for two days at $30^{\circ} \mathrm{C}, 200$ $\mathrm{rpm}$ shaken. For preparation of spore of $S$. cerevisiae MF1005, the culture was centrifuged at 12,000 rpm for $5 \mathrm{~min}$ in a Microfuge centrifuge (Beckman Coulter), the cell was collected and washed three times with sterilized deionized water, then inoculated into sporulation medium containing $1 \%$ potassium acetate, $0.1 \%$ yeast extract, and $0.05 \%$ glucose (modified from Tong and Boone, 2006) for cell sporulation at $27^{\circ} \mathrm{C}$, shaken at $130 \mathrm{rpm}$ for 5 days. The cell number of inoculation was adjusted to $2 \sim 3 \times 10^{8} / \mathrm{mL}$. The spores, observed by microscopy, were more than $97 \%$ pure after sporulation. The spore of $T$. viride was prepared by cultivating the strain on spreading agar plate of YPDM medium at $30^{\circ} \mathrm{C}$ for 7 days. The spore grown on the plate was washed down using sterilized deionized water and collected.

\section{Preparation of DNA}

The cell, mycelium or spore was used for extraction of genomic DNA. The cells and spores were collected by centrifuging the culture or spore suspension at 12,000 rpm for 5 min. The mycelium was collected by filtering the culture of $T$. viride through a filter paper. The pellet of cells, spore or mycelium was washed three times with deionized water, and then harvested finally for preparation of DNA. The extraction of DNA was performed in two steps [defined as a two-step extraction (TSE) method]: the first step was used for disrupting the wall of cell or spore; $0.1 \mathrm{~g}$ cell, spore or mycelium was put into the sample cup of the device (Figure 1), together with $300 \mathrm{mg}$ dried sterilized silica sand, of $0.6-1.2 \mathrm{~mm}$ in diameter, ground at $8000 \mathrm{rpm}$ for $2 \mathrm{~min}$ (measured by a stopwatch). The sample was ground into sludge. The second step was used to further break down the samples for extracting the DNA. After the first step, the grind stone was drawn out from sample cup, $1000 \mu \mathrm{L}$ extraction buffer (200 $\mathrm{mM}$ Tris-HCL, pH 7.5, $250 \mathrm{mM} \mathrm{NaCl}, 25 \mathrm{mM}$ EDTA, 0.5\% SDS and 0.2\% TritonX-100) was added. Then, the sample sludge was ground for a further $2 \mathrm{~min}$ in the device at the same 
rotation speed. Then, the grind stone was drawn out from the sample cup again. The sample was stored, resting for 3-5 min in the sample cup for debris sedimentation. Five hundred microliters of supernatant was transferred into a fresh $1.5-\mathrm{mL}$ Eppendorf microcentrifuge. The DNA in supernatant was further purified according to the normal phenol/chloroform protocol. The sample cup was kept in an ice bath during the entire extraction process. The purified DNA was then dissolved in $1 \mathrm{X}$ TE buffer ( $\mathrm{pH} 8.0$, containing $50 \mu \mathrm{g} / \mathrm{mL}$ RNase) and stored at $-20^{\circ} \mathrm{C}$ for further experiments. After extraction the sample cup and grind stone were brushed clean completely with detergent and the detergent rinsed away with water, then immersed in $10 \%$ sodium hypochlorite solution for 1 min for decontamination (Deden et al., 2006), and finally rinsed with deionized water and $75 \%(\mathrm{v} / \mathrm{v})$ ethanol followed by drying with sterilized filter paper. After cleaned and dried the sample cup and grind stone was then used for next extraction. No cross-contamination was detected during our experiments.

For comparison the QS method reported by Chi et al. (2009), using one-step procedure for extracting the genomic DNA from fungi, was used as a control method. The control extraction was performed according to the QS method where the sample was ground for $2 \mathrm{~s}$ without addition of silica sand and $1 \mathrm{M} \mathrm{KCl}$ buffer was used for extraction of DNA. The major difference between QS and TSE is shown in Table 1.

Table 1. Comparison of quick and safe (QS) and two-step extraction (TSE) method.

\begin{tabular}{lll}
\hline Item & QS* & TSE \\
\hline Extraction step & One step & Two steps \\
Grinding medium & No & Silica sand \\
Grinding time & $2 \mathrm{~s}$ & $2 \mathrm{x} 2 \mathrm{~min}$ \\
Extraction buffer & $1 \mathrm{M} \mathrm{KCl}, 100 \mathrm{mM}$ Tris-HCl, $\mathrm{pH} 8.0$, & $200 \mathrm{mM} \mathrm{Tris} \mathrm{HCl,} \mathrm{pH} 7.5,250 \mathrm{mM} \mathrm{NaCl}$, \\
& $10 \mathrm{mM} \mathrm{EDTA}$, no lysis regent added & $25 \mathrm{mM} \mathrm{EDTA}, 0.5 \% \mathrm{SDS}$, and $0.2 \%$ TritonX-100 \\
Purification & Ethanol precipitation & Phenol/chloroform extraction then ethanol precipitation \\
\hline
\end{tabular}

*Method of Chi et al., 2009.

\section{DNA analysis}

The yield and purity of extracted DNA was determined by spectrophotometry with NanoDrop 2000C Spectrophotometer (Thermo-Scientific, USA). The purity of the DNA was estimated by calculating $\mathrm{A}_{260} / \mathrm{A}_{280}$ and $\mathrm{A}_{260} / \mathrm{A}_{230}$. The fragment length of DNA was determined by agarose gel electrophoresis.

\section{PCR assay}

The extracted genomic DNA from six microorganism samples were used as templates for PCR amplification of four genes, leuABCD, 16s rDNA, GAL 1, and cbh2. The primers for PCR are shown in Table 2. Each $50 \mu \mathrm{L}$ PCR contained 2.5 U Takara LA Taq ${ }^{\circledR}$ DNA polymerase, 1X LA PCR buffer II ( $\mathrm{Mg}^{2+}$ Plus), $0.2 \mathrm{mM}$ deoxyribonucleoside triphosphates, 0.5 $\mu \mathrm{moL}$ of both the primers and $1 \mu \mathrm{L}$ DNA sample. Reaction condition was set up according to the instruction manual of Takara LA Taq ${ }^{\circledR}$ DNA polymerase, e.g., initial denaturing at $94^{\circ} \mathrm{C}$ for $1 \mathrm{~min}, 30$ cycles of denaturing at $98^{\circ} \mathrm{C}$ for $10 \mathrm{~s}$, annealing and extension at $68^{\circ} \mathrm{C}$ for $1.6 \sim 5.0$ $\min (1 \mathrm{~kb} / \mathrm{min})$ and a final extension at $72^{\circ} \mathrm{C}$ for $10 \mathrm{~min}$. The PCR product was stored at $-20^{\circ} \mathrm{C}$ for electrophoresis assay. 
Table 2. The PCR primer sets used in this study.

\begin{tabular}{|c|c|}
\hline Targer DNA & Primer sequence \\
\hline leuABCD & $\begin{array}{l}\text { F: 5'-AAGAGACAAGGACCCAAACCATGAGCCAG-3' } \\
\text { R: 5'-TTAATTCATAAACGCAGGTTGTTTTGC-3' }\end{array}$ \\
\hline 16s rDNA & F: 5'-AGAGTTTGATCMTGGCTCAG-3' \\
\hline GAL 1 & $\begin{array}{l}\text { F: 5'-TTATTGTGATAGTATCTCAGCG-3' } \\
\text { R: 5'-AAAAGTGTACTACTCGTTATT-3' }\end{array}$ \\
\hline $\operatorname{cbh} 2$ & $\begin{array}{l}\text { F: 5'-AGTTGCTCATTTGCGGTCTACC-3' } \\
\text { R: 5'-GGGCTTTATCCTGTGCTCCCGAdirect-3' }\end{array}$ \\
\hline
\end{tabular}

\section{Electrophoresis}

The extracted genomic DNA and PCR products were assayed using electrophoresis through $0.8 \%$ agarose gels in TAE ( 2 mM EDTA, $40 \mathrm{mM}$ Tris-acetate, $\mathrm{pH} 8.0$ ) and were visualized by staining with Genefinder ${ }^{\mathrm{TM}}$ stain (SBS Genetech, China). The electrophoresis image was obtained by using Gel Doc ${ }^{\mathrm{TM}}$ XR (Bio-Rad, USA) digital gel documentation system.

\section{RESULTS AND DISCUSSION}

\section{Yield and purity}

Six microbial samples with a different cell wall structure were used for exploring the feasibility of TSE method. The QS method was selected as a control for comparison since it used a similar device as TSE for DNA preparation except that the extraction condition and the buffer used was different (Table 1).

The $\mathrm{A}_{260} / \mathrm{A}_{280}$ and $\mathrm{A}_{260} / \mathrm{A}_{230}$ of DNA extracted by both TSE and QS method were 1.81.9 and 2.1-2.2 (results not shown), indicating that the DNA extracted by both methods was relatively free from contamination of RNA and protein.

The yield of DNA extraction is shown in Figure 2. When the sample amount was 0.1 $\mathrm{g}$ and the final volume of DNA solution was adjusted to $100 \mu \mathrm{L}$, the yield of DNA extracted by TSE method from six samples was $1480.5 \mathrm{ng} / \mu \mathrm{L}$ (E. coli JM109), $293.6 \mathrm{ng} / \mu \mathrm{L}$ (B. subtilis WB600), $226.3 \mathrm{ng} / \mu \mathrm{L}$ (S. cerevisiae INVSc1), $689.5 \mathrm{ng} / \mu \mathrm{L}$ (T. viride AS3.3711), $94.9 \mathrm{ng} / \mu \mathrm{L}$ (spore of $S$. cerevisiae MF1005) and $66.2 \mathrm{ng} / \mu \mathrm{L}$ (spore of T. viride AS3.3711). It is known that the cell envelopes of microorganisms vary in structure between taxonomic groups (Maarit et al., 2001). The fact that the DNA yield was significantly different between the samples indicates that the wall structure of microbial cells or spores significantly affects the extraction of genomic DNA. This result is consistent with the previous investigation. Niwa et al. (2005) have reported that the thick cell walls of Gram-positive bacteria, which contain the covalently linkage of peptidoglycans, are not easily disrupted. The yeast cell walls are also not readily susceptible to lysis (Müller et al., 1998). The cell walls of some species of fungi, for example cladosporioid species, hamper the extraction of genomic DNA from their cells (Moslem et al., 2010). The thick wall of microbial spore extremely impedes the extraction of DNA (Kuske et al., 1998; Waites et al., 2001). However, not only from vegetative cell sample, but also from the spores of $S$. cerevisiae and $T$. viride, a significant amount of genomic DNA was extracted by the TSE method, even if the yield from spores were lower than that from vegetative cells. 
Comparing with QS, the yield of TSE protocol was much higher. The increment for vegetative cell samples was from 2.18- to 5.43-fold, with a maximal increase, which occurred to $E$. coli (5.43-fold). Furthermore, no significant genomic DNA was extracted from the spores by the QS method. These results demonstrate that TSE is a more effective method for extracting genomic DNA from various microbial samples than QS. The major difference between two methods (Table 1) indicates that TSE significantly increased DNA yield by using two-step grinding, which had more effectively disrupted the wall of microbial cell or spore, and by using a more effective extraction buffer.

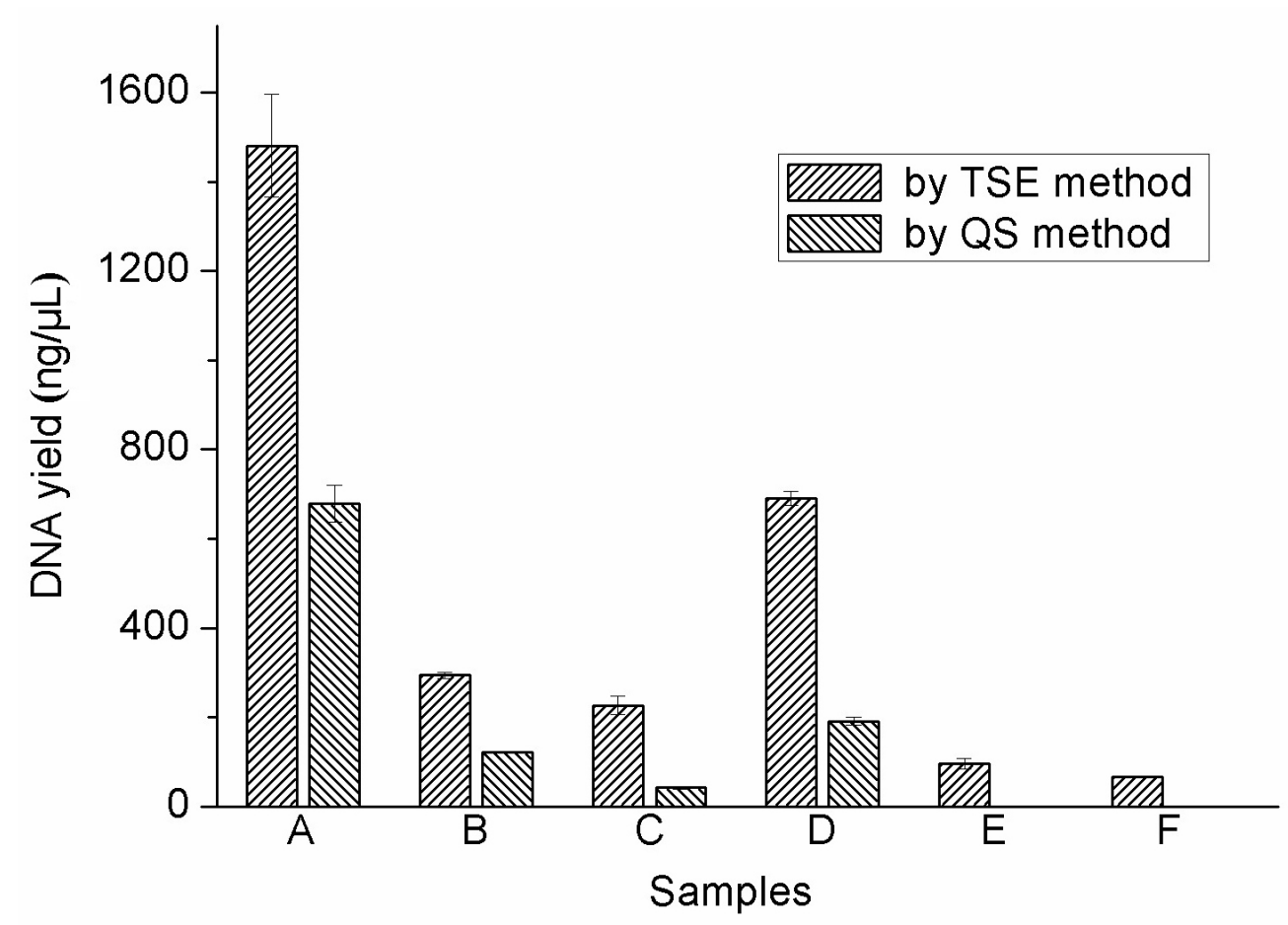

Figure 2. Comparison of DNA yield between two-step extraction (TSE) and quick and safe (QS). A = Cell of Escherichia coli JM109; B = cell of Bacillus subtilis WB600; C = cell of Sacchromyces cerevisiae INVSc1; D = mycelium of Trichoderma viride AS3.3711; E = spore of S. cerevisiae MF1005; F = spore of T. viride AS3.3711. The genomic DNA extracted by the QS method from spores of $S$. cerevisiae and $T$. viride was not detected.

\section{DNA fragment length and PCR suitability}

The images of agarose gel electrophoresis showed that the fragments of DNA extracted by both TSE and QS had all exceeded $23 \mathrm{~kb}$, no degradation of DNA was observed in the electrophoresis (Figure 3), indicating that the grinding operation of TSE did not significantly reduce the fragment size of extracted DNA. Furthermore, the visual band in the electrophoresis gel showed that the DNA yield extracted by TSE was much higher than that by QS, and no significant DNA was extracted by QS from both spore samples. The results were consistent with the yield determination (Figure 2). 


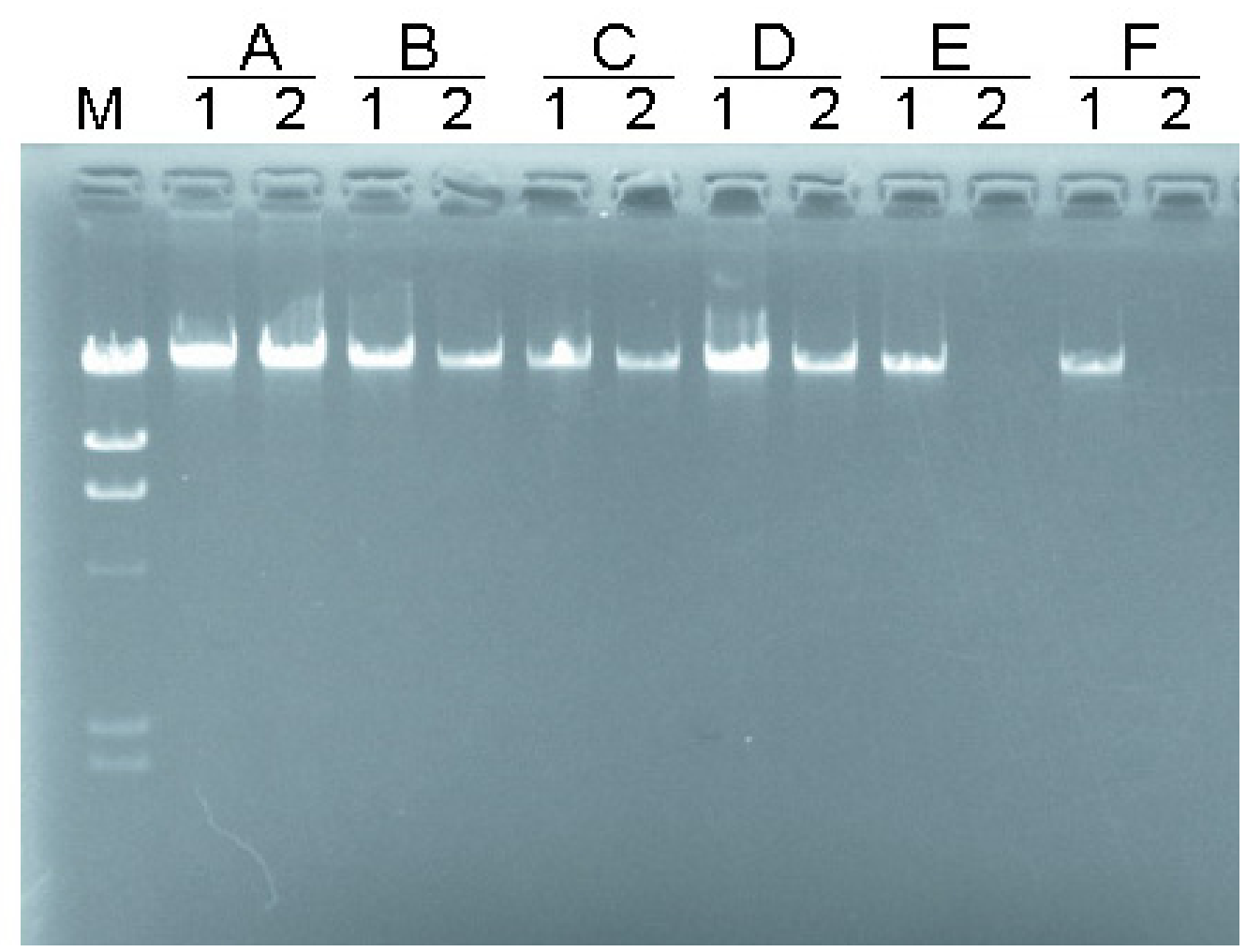

Figure 3. Electrophoresis of genomic DNA. Lane $M=\lambda$ HindIII DNA marker; lane A = cell of Escherichia coli JM109; lane $B=$ cell of Bacillus subtilis WB600; lane $C=$ cell of Sacchromyces cerevisiae INVSc1; lane D = mycelium of Trichoderma viride AS3.3711; lane $E=$ spore of $S$. cerevisiae MF1005; lane $F=$ spore of $T$. viride AS3.3711; lane $1=$ extracted by two-step extraction; lane 2 = extracted by quick and safe. The genomic DNA extracted by quick and safe from spores of S. cerevisiae (lane E2) and T. viride (lane F2) was not observed in the visual band on the electrophoresis gel.

For estimating the integrity, the extracted DNA was used as templates for PCR amplification of four target sequences of different length (1500, 1697, 2690, and $4702 \mathrm{bp})$. The PCR product was assayed by agarose gel electrophoresis. With six DNA samples extracted by TSE as templates, the four target DNA sequences were successfully and exclusively amplified (Figure 4). But when DNA extracted by the QS method was used as templates, only two sequences (leuABCD, $4702 \mathrm{bp}$ and $c b h 2,1697 \mathrm{bp}$ ) were amplified successfully, and the amplification of the other two sequences (16s rDNA, and GAL 1) was not observed on the electrophoresis gel (Figure 4). In Figure 2, we can see that the DNA extracted by using the QS method from B. subtilis WB600 and S. cerevisiae INVSc1, which were used for amplification of $16 \mathrm{~s}$ rDNA (1500 bp) and GAL 1 (2690 bp), was much lower in concentration than that extracted from the other two vegetative cell samples, and the DNA isolated by QS protocol from both spore samples was performed under the detection limit of spectrophotometry, therefore, the failure amplification by using QS extracting DNA as templates was due to the too low concentration of templates to meet the PCR requirements. Thus, in view of the need for PCR, the TSE method is more favorable than the QS method for the preparation of genomic DNA from diverse microbial samples. 


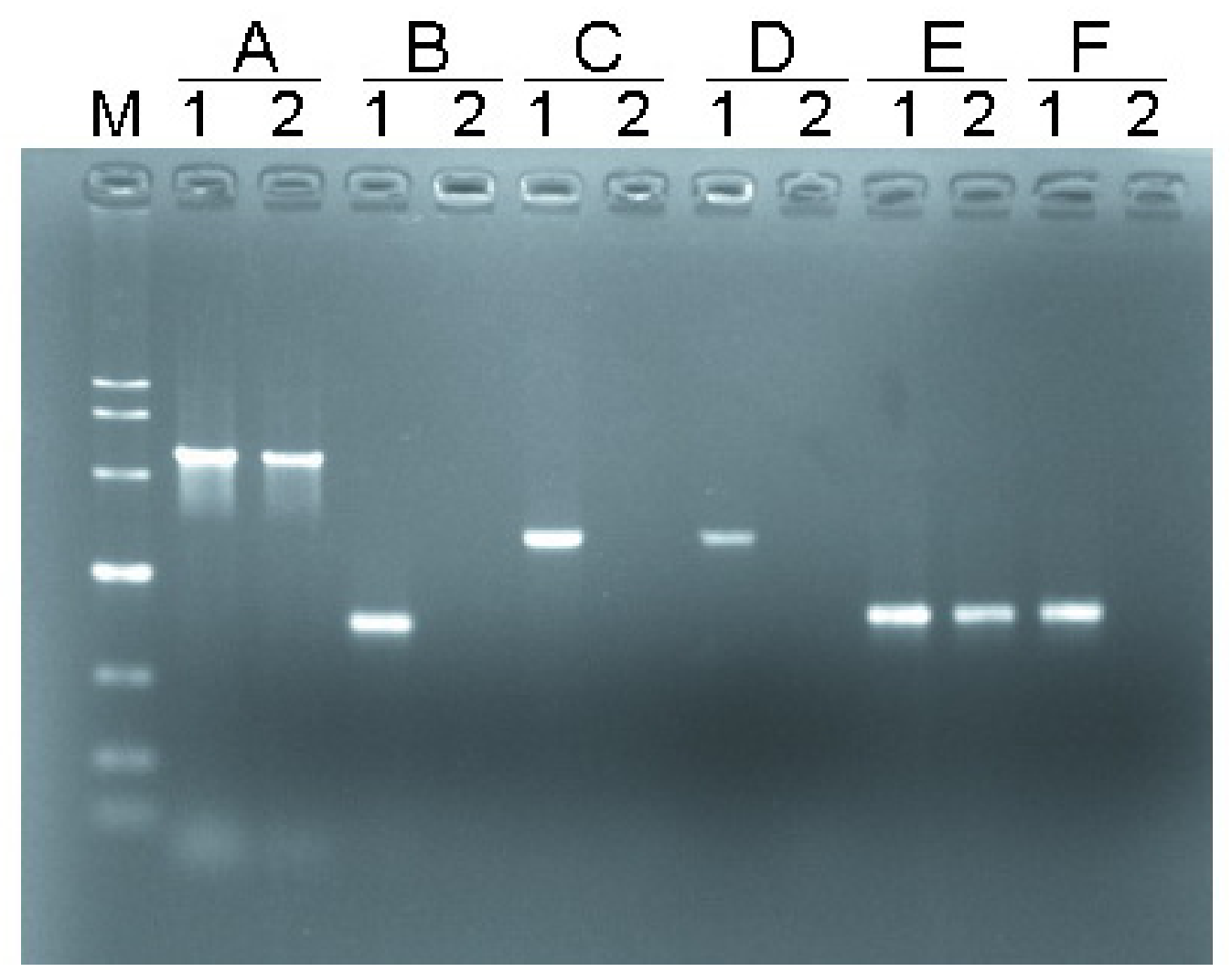

Figure 4. Electrophoresis of PCR products amplified from genomic DNA. Lane $M=$ DL10,000 DNA marker (Takara code D504A); lane $A=$ leuABCD amplified from cell of Escherichia coli JM109; lane B = 16s rDNA amplified from cell of Bacillus subtilis WB600; lane $C=G A L 1$ amplified from cell of Sacchromyces cerevisiae INVSc1; lane $D=G A L 1$ amplified from spores of $S$. cerevisiae MF1005; lane $E=c b h 2$ amplified from mycelium of Trichoderma viride AS3.3711; lane $F=c b h 2$ amplified from spore of $T$. viride AS3.3711; lane $1=$ the template DNA was extracted by two-step extraction; lane $2=$ the template DNA was extracted by quick and safe.

\section{Advantage}

There are already commercial available devices for preparation of DNA from cells or tissues based on the disruption of cells with a mini-grinder (Al-Samarrai and Schmid, 2000; Astegiano et al., 2010; Moslem et al., 2010). TissueRuptor (Qiagen, Germany) (Astegiano et al., 2010) is one of these kinds of devices widely used by reported investigation. However, the protocol of TissueRuptor, which is similar to the QS method, is designed to be only suitable for treatment of a small sample amount. Compared to the TissueRuptor procedure, the TSE method has a greater advantage for preparation of DNA from larger amounts of microbial samples. The above results have shown that it is at least suitable to extract genomic DNA from most types of microbial samples, including the spores of microorganism with the thicker wall that greatly impede the extraction of genomic DNA. By modifying the sample cup capacity and using a suitable grind stone the TSE method can be used for treatment of various amounts 
of samples. The capacity of sample cup can be enlarged or reduced much easily by lathing the polytetrafluoroethylene rod. A suitable grind stone can be easily obtained from the market suppliers. The sample cup and grind stone could be repeatedly used after washing and decontamination in $10 \%$ sodium hypochlorite. Therefore, a laboratory can prepare several sets of devices with numerous sample cups of various capacities and suitable grind stones to perform extraction of genomic DNA from a large number of microbial samples at onetime. Based on our experience, the entire extraction could be finished within $1.5 \mathrm{~h}$ (about $10 \mathrm{~min}$ for cell or spore collected, $5 \mathrm{~min}$ for two-step extraction, $60 \mathrm{~min}$ for purification and precipitation of DNA). During the precipitation (about $30 \mathrm{~min}$ ) the researcher can perform another two-step extraction in order to speed up the preparation.

Thus, our results suggest that TSE is a simple and more favorable method for preparation of DNA from various microbial samples, especially suitable for institutes in developing countries with limited financial support.

\section{CONCLUSION}

To extract the genomic DNA from microbial samples, a novel method referred to as TSE, was reported. The feature of the method was that the DNA was extracted by a two-step extraction procedure using a novel device and an effective extraction buffer containing lysis chemicals. From six samples, of which four vegetative cell samples, respectively, were representative of Gram-negative bacteria, Gram-positive bacteria, yeasts, and filamentous fungi, two species of spores representing the samples extremely hampered the extraction of DNA due to their thicker cell wall. Nevertheless, the genomic DNAs were efficiently extracted by the TSE method. With the extracted DNA as templates the target sequences up to about $5 \mathrm{~kb}$ were successfully and exclusively amplified by PCR. TSE is a simple and effective method for extracting genomic DNA from various microbial samples.

\section{ACKNOWLEDGMENTS}

Research supported by the International Science \& Technology Cooperation Program of China (\#2010DFB63590), the National Basic Research Program of China (\#2010CB736209), the Scientist \& Technician Servicing Enterprise Project of China (\#2009GJE10002), the Ministry of Science and Technology of the People's Republic of China, the Natural Science Foundation Project of Guangxi, China (\#2011GXNSFA018113), and the Scientific Technology Research Project of Guangxi, China (\#10100019-21, \#1140010-15).

\section{REFERENCES}

Al-Samarrai TH and Schmid J (2000). A simple method for extraction of fungal genomic DNA. Lett. Appl. Microbiol. 30: 53-56.

Astegiano S, Sidoti F, Costa C, Ostorero A, et al. (2010). Human cytomegalovirus load in fresh and glycerolized skin grafts. New Microbiol. 33: 253-256.

Chi MH, Park SY and Lee YH (2009). A quick and safe method for fungal DNA extraction. Plant Pathol. J. 25: 108-111.

Clark-Curtiss JE, Jacobs WR, Docherty MA, Ritchie LR, et al. (1985). Molecular analysis of DNA and construction of genomic libraries of Mycobacterium leprae. J. Bacteriol. 161: 1093-1102.

Deden H, Deufel A, Eisel D and Grünewald-Janho S (2006). PCR Applications Manual. 3rd edn. Roche Diagnostics GmbH, Mannheim. 
Fredricks DN and Relman DA (1998). Improved amplification of microbial DNA from blood cultures by removal of the PCR inhibitor sodium polyanetholesulfonate. J. Clin. Microbiol. 36: 2810-2816.

Griffiths LJ, Anyim M, Doffman SR, Wilks M, et al. (2006). Comparison of DNA extraction methods for Aspergillus fumigatus using real-time PCR. J. Med. Microbiol. 55: 1187-1191.

Harju S, Fedosyuk H and Peterson KR (2004). Rapid isolation of yeast genomic DNA: Bust n' Grab. BMC Biotechnol. 4: 8.

Karakousis A, Tan L, Ellis D, Alexiou H, et al. (2006). An assessment of the efficiency of fungal DNA extraction methods for maximizing the detection of medically important fungi using PCR. J. Microbiol. Methods 65: 38-48.

Kuske CR, Banton KL, Adorada DL, Stark PC, et al. (1998). Small-scale DNA sample preparation method for field PCR detection of microbial cells and spores in soil. Appl. Environ. Microbiol. 64: 2463-2472.

Liu KH, Yeh YL and Shen WC (2011). Fast preparation of fungal DNA for PCR screening. J. Microbiol. Methods 85: $170-172$.

Maarit NR, Heiskanen I, Wallenius K and Lindstrom K (2001). Extraction and purification of DNA in rhizosphere soil samples for PCR-DGGE analysis of bacterial consortia. J. Microbiol. Methods 45: 155-165.

Melo SC, Pungartnik C, Cascardo JC and Brendel M (2006). Rapid and efficient protocol for DNA extraction and molecular identification of the basidiomycete Crinipellis perniciosa. Genet. Mol. Res. 5: 851-855.

Moslem MA, Bahkali AH, Abd-Elsalam KA and Wit PJ (2010). An efficient method for DNA extraction from Cladosporioid fungi. Genet. Mol. Res. 9: 2283-2291.

Müller FM, Werner KE, Kasai M, Francesconi A, et al. (1998). Rapid extraction of genomic DNA from medically important yeasts and filamentous fungi by high-speed cell disruption. J. Clin. Microbiol. 36: 1625-1629.

Niwa T, Kawamura Y, Katagiri Y and Ezaki T (2005). Lytic enzyme, labiase for a broad range of Gram-positive bacteria and its application to analyze functional DNA/RNA. J. Microbiol. Methods 61: 251-260.

Okada H, Tada K, Sekiya T, Yokoyama K, et al. (1998). Molecular characterization and heterologous expression of the gene encoding a low-molecular-mass endoglucanase from Trichoderma reesei QM9414. Appl. Environ. Microbiol. 64: 555-563.

Rajagopalan G and Krishnan C (2008). Alpha-amylase production from catabolite derepressed Bacillus subtilis KCC103 utilizing sugarcane bagasse hydrolysate. Bioresour. Technol. 99: 3044-3050.

Sambrook J and Russell DW (2001). Molecular Cloning: A Laboratory Manual. 3rd edn. Cold Spring Harbor, New York.

Tendulkar SR, Gupta A and Chattoo BB (2003). A simple protocol for isolation of fungal DNA. Biotechnol. Lett. 25: 1941-1944.

Tong AH and Boone C (2006). Synthetic genetic array analysis in Saccharomyces cerevisiae. Methods Mol. Biol. 313: 171-192.

Waites MJ, Morgan NL, Rockey JS and Higton G (2001). Industrial Microbiology: An Introduction. Blackwell Science, London, 16-34.

Yamamoto Y, Kohno S, Koga H, Kakeya H, et al. (1995). Random amplified polymorphic DNA analysis of clinically and environmentally isolated Cryptococcus neoformans in Nagasaki. J. Clin. Microbiol. 33: 3328-3332.

Zhang YJ, Zhang S, Liu XZ, Wen HA, et al. (2010). A simple method of genomic DNA extraction suitable for analysis of bulk fungal strains. Lett. Appl. Microbiol. 51: 114-118. 


\section{SUPPLEMENTARY MATERIAL}

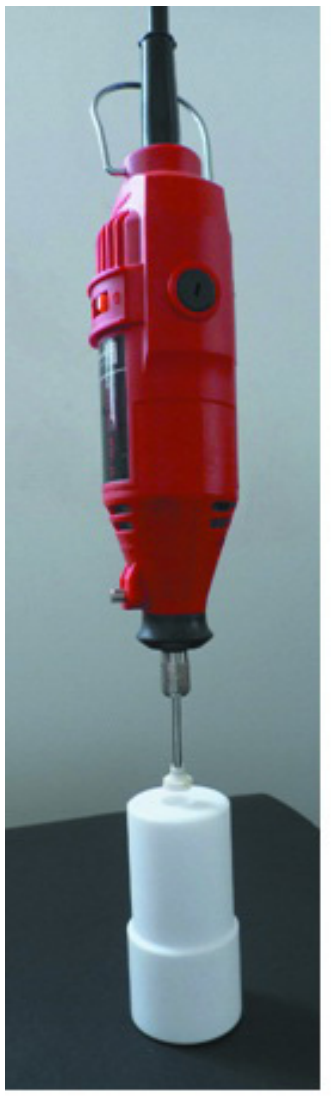

A

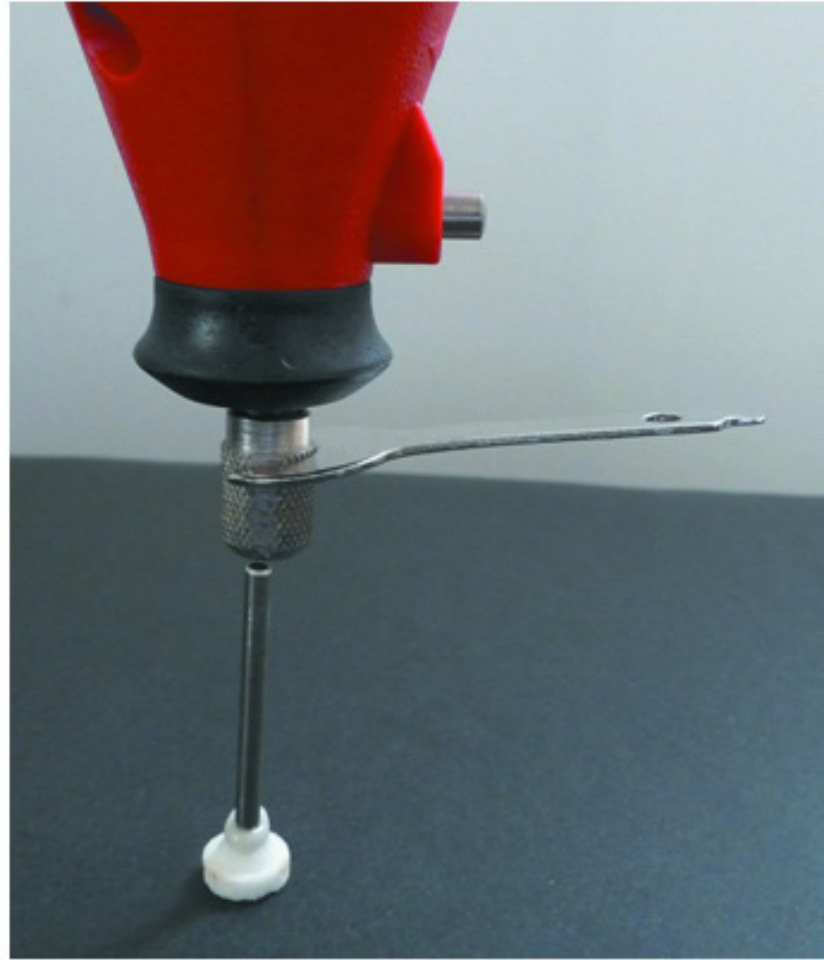

B

Supplementary Figure 1. Photos of the novel self-designed device used in this study. A. Shows the device used for extraction of genomic DNA from microbial samples. B. Shows that the adaptor fixes the grind stone by tightening the screw of adaptor matching the axis of grinder with a spanner. 